The Northern Review

yukoncollege.yk.ca/review

\title{
Essay
}

\section{Rethinking Inequality in a Northern Indigenous Context: Affluence, Poverty, and the Racial Reconfiguration and Redistribution of Wealth}

Peter Kulchyski

\section{The Racial Reconfiguration and Redistribution of Wealth}

Canada represents a material and ideological structure designed to support a racially oriented reconfiguration and redistribution of wealth. That is, the settler colonial nation-state of Canada depends upon and aggressively supports changing the forms of wealth that Indigenous people had and have into forms amenable to the accumulation of capital, which in turn enables extracting that wealth for the benefit of southern, "white" and, especially, elite social fragments. What is called inequality is not an accidental by-product of this process, or the result of a few misguided policies, but is a core, foundational, structural feature of contemporary Canadian society, supported by an integrated set of legal, political, cultural, social, and economic systems. What follows is an attempt to "unpack" or elaborate the foregoing argument, with particular attention to the manner in which Indigenous ways of life challenge dominant notions of wealth and poverty, and concurrent attention to how the broader discourse on inequality itself adopts a few assumptions about the nature of wealth, which may be in need of challenging.

The 2008 global financial crisis has led to a broad public debate about rising levels of inequality. The debate was given some impetus by the publication of Thomas Picketty's Capital in the Twenty-First Century, which made a global argument about increasing levels of inequality, 
and was also central to the "Occupy" movement's call for social change. The terms of the debate, however, have been almost entirely within the logical and discursive parameters of the capitalist economy. Hence, the easiest measures of inequality are wages of workers versus wages of chief economic officers, for example, a relative measure that has particularly deteriorated in the neo-liberal era. The neo-liberal era involved an intensification of capital accumulation largely through the redistribution of wealth upwards: the state became a vehicle for increasing corporate profits at the expense of expanding social programs. So the debate often tends towards arguments about corporate taxation levels, appropriate degrees of social support (especially health care), and the level of minimum wages: measurable indicators that can, across society and within the logic of the capitalist system, alleviate or reduce inequality. While Marxists argue, correctly in my view, that inasmuch as the system depends upon the exploitation of working people and is therefore structurally founded upon the creation and reproduction of inequality, it is still the case that the line of argument-except for revolutionaries-leads to the forms of amelioration noted above: greater corporate taxation, more social programs, higher minimum wages.

From a global perspective, the Canadian North represents a region where this logic urgently needs to be supplemented. The bush mode of production is still an everyday part of life in northern Indigenous communities. That means Dene, Inuit, Metis, and other northern peoples cannot be treated as a fragment of the working class whose problems can be ameliorated with higher wages. Something else is going on, a different dynamic is taking place in which the imposition of a dominant way of life is a part of the politics of oppression and resistance. And this "something else" demands attention.

Two well-known thinkers help elucidate the specific politics of northern hunters in broad global terms. In Capital, Volume One, Karl Marx described the process of separating people from their land as a central structural feature of capitalism, writing in a well-known passage:

In the history of primitive accumulation, all revolutions are epoch-making that act as levers for the capitalist class in the course of its formation; but this is true above all for those moments when great masses of men are suddenly and forcibly torn from the means of subsistence, and hurled onto the labour market as free, unprotected and rightless proletarians. (876) 
Marx used the concept "primitive accumulation" to describe what I have called the racial reconfiguration and redistribution of wealth. Being "torn from the means of subsistence" means being separated from the land, a process northern hunters continue to struggle with. In the essays collected in Customs in Common, the great British social historian Edward Thompson had rather a lot to say about the struggle over tearing people from their means of subsistence, noting, for example, that "perhaps in the first six decades of the eighteenth century disputes about deer and other game, about fishing rights, about timber, about the exploitation of quarries, sand pits and peat, became more frequent and more angry" (106). What created these disputes was the totalizing spread of a quite different regime of property: "the concept of exclusive property in land, as a norm to which other practices must be adjusted, was now extending across the whole globe, like a coinage reducing all things to a common measure" (164).

While a number of thinkers (myself included, but see also David Harvey) have gained traction in recent years by arguing that "primitive accumulation" was not something that only happened in the early years of capitalism (that is, late eighteenth or early nineteenth century), but continues as a critical feature of capitalism today, Thompson saw this clearly in an essay he wrote in 1967: "what was said by the mercantilist moralists as to the failures of the eighteenth-century English poor to respond to the incentives and disciplines is often repeated, by observers and by theorists of economic growth, of the peoples of developing countries today" (396).

Northern Canada is a battleground, and the battle is over land use. The advocates of what is called "development" want to turn the land into a resource base in which raw materials are shipped south to power commodity production or to be turned into commodities. At the best, they argue that this will create a certain amount of temporary wage employment for some Indigenous people. For Indigenous hunting people, the racial reconfiguration and redistribution of wealth, or primitive accumulation, is about the destruction of a way of life through taking away the "means of subsistence," access to the land: this is the politics that needs to be understood before the issue of inequality gets raised. Raising taxation levels on the resource extraction companies, or raising the wage levels of Indigenous workers, or, again, developing a better social safety net, while not unimportant, are largely issues to the side of the major struggle over how the land will be used. 


\section{The Gillam Model of Development}

This is not to say that inequality does not exist in the North, rather that inequality needs to be framed within the context of an understanding or an appreciation of the nature of a struggle that represents different ways of life colliding. All across the provincial and Far North, the inequality that exists is starkly evident. There are basically two kinds of "small-town Norths" that exist. On the one hand, the industry towns of miners, loggers, oil-patch workers, hydro employees, and so on: the Kenoras, Thompsons, Prince Georges with their large white working-class populations and their paved roads and fully modernized infrastructures, facilities, and amenities. On the other hand, the Colville Lakes, the Old Crows, the Lac Brochets, with their Dene and Cree and Anishnabe and Inuit citizens and their isolation, often through lack of all-season road access, and gravel streets, water delivery, rundown everything, perpetual housing crises.

Of course, both social existences can often be found in the same place, as in Grand Rapids or Gillam, in northern Manitoba. In Gillam, a crown corporation, Manitoba Hydro, has built a suburban paradise for its workers, with detached houses, paved roads, lawns, and two hydro meters so they can subsidize employee's heating costs. Right next to these are the poorly insulated trailers ("mobile modular units" is how Hydro's executives refer to them) that local Fox Lake Cree Nation citizens occupy. When you pay so much for the electrical heat, there's little left over for such amenities as, well, food; never mind a pass for your children into the local swimming pool.

Today, in 2015, you have to wonder, if you're a young Inninewak girl or boy growing up in Gillam, and your neighbour's parents can buy them the latest computer gadgets, and they have a pass to the swimming pool, and the latest styles of clothes, and, and, and ... You have to wonder if there's something wrong with you, or with your parents: why they have so much and you have so little. In a racialized context, the problem is even more aggravated. It is as if someone read Franz Fanon's words, always worth repeating, about the town of the colonized and the town of the colonizers and instead of seeing this as a criticism, used them as a design model: 
The settlers' town is a strongly built town, all made of stone and steel. It is a brightly lit town; the streets are covered with asphalt, and the garbage cans swallow all the leavings, unseen, unknown and hardly thought about. The settler's feet are never visible, except perhaps in the sea; but there you're never close enough to see them. His feet are protected by strong shoes although the streets of his town are clean and even, with no holes or stones. The settler's town is a well-fed town, an easygoing town; its belly is always full of good things. The settlers' town is a town of white people, of foreigners.

The town belonging to the colonized people, or at least the native town, the Negro village, the medina, the reservation, is a place of ill fame, peopled by men of evil repute. They are born there, it matters little where or how; they die there, it matters not where, nor how. It is a world without spaciousness; men live there on top of each other, and their huts are built one on top of the other. The native town is a hungry town, starved of bread, of meat, of shoes, of coal, of light. The native town is a crouching village, a town on its knees, a town wallowing in the mire. It is a town of niggers and dirty Arabs. (39)

This can be called the Gillam model of development and it can be found all across the provincial and Far North of Canada. Most often the communities are comfortably separated by space so they do not have to be in close proximity. But in certain places, like Gillam, they are pushed up against each other. Where Indigenous communities are remote and isolated, the sting of inequality may not be as sharp. Where everyone is poor (at least, poor in terms of the dominant popular culture: we'll return to the question of defining wealth and poverty below), there is no shame in poverty. It is the shame that is the genuinely soul-destroying element of poverty, and that shame can happen when people's material needs are taken care of but they live side by side with people who enjoy more wealth, particularly when there are cultural, racial, or gender differences at play. The "vision," if it can be called that, of government officials and development economists alike, is one, ten, a thousand Gillams in northern Canada.

\section{The Original Affluent Society: Again!}

Another white male thinker to add to the mix: the anthropologist Marshall Sahlins. His collection of essays in Stone Age Economics begins with a very widely read one called "The Original Affluent Society" in which he argues that hunting peoples have been seriously underestimated by pretty 
much the entire Western world, including economists, social scientists, philosophers, and historians. The essay makes a number of intertwined and critical arguments that deserve repeated attention. Allow me to repeat the comments I made about his arguments in my book Like the Sound of a Drum:

Sahlins provides two broad reasons for his reevaluation [of hunting peoples]. On the one hand, he argues that gatherers and hunters have greater leisure time than any of the economies that followed, suggesting that "hunters keep banker's hours" (34-35). On the other hand, Sahlins argues that there exists "a Zen road to affluence" (2), that gatherers and hunters can take 'the path of least resistance' in the language of classical zen philosophy. Simply put, gatherers and hunters have fewer needs and those needs are relatively easily met. Any individual can make with her own hands the things she needs to survive and thrive. Moreover, there is a material limit that conditions the need structure. This material limit is an exigency that derives from the nomadic way of life of most gatherers and hunters. Again, simply put, in a society where you can only own what you can carry, your ownership or ability to accumulate has an upper limit. Sahlins writes: "of the hunter it is truly said that his wealth is a burden. In his condition of life, good can become 'grievously oppressive', as Guisinde observes, and the more so the longer they are carried around" (11).

In this social context, objects must be viewed, not with the desire that we are increasingly provoked to adopt as an attitude towards things, but rather with suspicion. For these reasons, Sahlins argues persuasively that:

Hunting and gathering has all the strengths of its weaknesses. Periodic movement and restraint in wealth and population are at once imperatives of the economic practice and creative adaptations, the kinds of necessities of which virtues are made. Precisely in such a framework, affluence becomes possible (34).

Conversely, it is the world that carefully harnesses its resources and creates massive surpluses the enjoyment of which is restricted to relatively few, where meaningful, systematic, impoverishment becomes equally possible if not probable: "poverty is not a certain small amount of goods, nor is it just a relation between means and ends; above all it is a relation between people. Poverty is a social status. As such it is the invention of civilization (37). (See 46-47) 
Ultimately, Sahlin's argument leads straight down the path that would question the nature of wealth and poverty themselves. His note that "poverty is a social status" is a reminder of the corrosive power of inequality, an endemic though entirely reprehensible feature of contemporary social life. It also affords an opening into rethinking wealth.

\section{Bush Wealth}

There are at least three forms of wealth that are being "reconfigured" through the racial reconfiguration and redistribution of wealth. They are the community, the land, and time. These three features of Indigenous life can be characterized as "bush wealth," the wealth of Indigenous northerners. Everywhere, they are under assault; everywhere they resist that assault. They are in the pores of Indigenous cultures, but entirely ignored by the busy-workers who want to decry the horrific social circumstances of Aboriginal peoples and develop culturally appropriate systems of assimilation: band-aids to staunch the bleeding. Indigenous cultures themselves might be thought of as a fourth form of wealth, albeit somewhat more intangible-a discussion worth engaging in some other context.

Northern Indigenous communities represent a quickly vanishing social form: intergenerational communities of production. The "community" is among the most banalized and debased terms used in modern life: the university community, the special community of $X$, the sports community. These ephemeral, alienated social collectives are (nearly) random groupings of conformist possessive individuals. From Hobbes through to Nancy, western philosophy has described communities in "presentest" terms, and forgets the intergenerational structure of lasting communities. Likewise, most communities we encounter are communities of consumption where the pleasure of enjoying a particular cultural commodity links us to others with the same taste-profile. So to appreciate the wealth of Indigenous communities requires a more intense thought process. A female Elder from Gillam, as it happens, named Nancy Beardy, publically tells her terrifying story of being sexually assaulted by construction workers building one of the three dams that surrounds her hometown. What stays with me is how, after many years of turmoil, she gets advice from another female elder, and through that regains her strength. In spite of the many indignities, deprivations, and worse that come with the inequality and poverty, it is support from others in her community that helps her carry on. 
Intergenerational communities of production allow for idiosyncratic individualism (that is, "character": there are more "characters" in most northern Indigenous communities than in any of the cookie-cutter suburbs that apparently prize individualism but never practice it), and allow for support networks, sympathy, empathy, tough love, an intimate knowledge of the strengths and weaknesses that flow down a family line through generations. Friendships and enmities, alliances and oppositions, jealousies and respects circulate across generations.

The Inninew seven generations teaching that I recently heard from Ron Cook in Thompson, Manitoba, does not look seven generations into the future, but rather thinks of the self as a middle generation, inheriting from parents, grandparents, and great-grandparents and passing values and knowledge to children, grandchildren, and great-grandchildren. That is, it is an embodied seven generations that can exist within living memory: the "I" that might have met a great-grandparent and may live long enough to meet a great-grandchild. Compared to such forms of community, we fans of The Simpsons or M.I.A. barely register.

Communities built upon these foundations are a form of wealth. This is a form of wealth that capitalism seeks to ruthlessly destroy. Communities, particularly those tied to land but in any meaningful form, are anathema to a form of wealth that depends upon a workforce mobile enough to move to where the latest productive centres are. Capitalism must disperse existing communities that are located inconveniently for its productive exigencies, and must concentrate people in areas where the growth cycle demands a new form of production. Bonds between people can form an obstacle to capital accumulation. Communities allow people to share, to survive without going to where the logic of capital needs them. The hollowing out of community is one of the great themes of the modern era. It is a reconfiguration of a form of wealth and it is taking place and being resisted now in Indigenous communities in northern Canada.

A second form of the wealth of northern Indigenous communities is their land base. This is particularly true where the water is still drinkable, where wildlife is still comparatively plentiful: in those places the land still provides. This is the critical "means of subsistence" that Marx wrote about. Indigenous intergenerational communities of production are based upon an intergenerational relationship to the land. People have stories about their great-grandparents or ancient ancestors; know where gravesites or sacred places or hunting or gathering or fishing grounds are to be found; and return to places that have layers of meaning for their families. A clean land means that instead of drinking water from bottles 
with pictures of glaciers on them, one can drink water that actually comes from glaciers. A clean land means eating fresh, "organic" wild meat and fish: expensive delicacies for the southern palate that are everyday meals for many Indigenous northerners.

The land is also a healing place. Most northern Indigenous communities have land-based programs, sometimes for people with addictions or with issues around criminal justice, or for youth. Somehow the beauty and tranquility of the land, or the lifestyle associated with being on the land, works to ease the troubles of those who reach the point where they need it.

Again, capitalism as a structure demands that ties to any particular land be severed so that people will be mobile as workers, so that people will not have any ability to create their own subsistence and will rely on the wage economy, so that, finally, the land itself will be available as a source of capital-wealth by being an agricultural or resource base. All that is sacred or beautiful on the land must fall prey to the bulldozer as quickly as possible, in the logic of the dominant order. The great struggles taking place all across northern Canada around land use are all versions of this grand historic, but not inevitable, process of severing people from the land and using land as a source of capital wealth. The Indigenous North in Canada has been an intensifying site of this particular struggle over the last century and a half-the struggle is far from over, but the attention and support given to it will have to come outside the logic of the usual inequality discussions.

Finally, a third form of bush wealth comes in the form of time. This turns us back to Sahlins's essay (and to E.P. Thompson's), and the argument that hunters actually had more leisure time than most people living in the contemporary era. It is my view that in bush cultures, that is, among hunting peoples, the very boundary between what is called "work" and what is called "leisure" is difficult to sustain. The quality and nature of "work" among Indigenous bush people is actually purchased for enjoyment as "leisure" by non-Indigenous people-often by the conventionally wealthy these days. To sit by a fishing hole in the ice, to travel upriver by jet boat waiting to spot a caribou, to tell a grandchild a story, to set up a camp, to patiently scrape a hide: all of these activities have elements of work and leisure associated with them. The very foundational categories of economics begin to fall away the closer we get to the bush mode of production-including the concept of wealth itself.

Perhaps the most important form of wealth anyone can have is time: time to philosophize, to rest, to undertake tasks at one's own pace, to spend 
with family and friends, to idle away. Compared to time, bank accounts and piles of things - the markers of wealth in the dominant culture-seem trivial, even frivolous. The time of the hunter, the wait, the expansions and contractions, the intense moment of the kill, this is a temporality barely, if at all, understood by modernity. It is within the parameters of this time that Indigenous peoples crafted their rich cultures; their layered, complex narratives; their profoundly respectful ethical systems; their relationships to each other, to the land, to all creation.

This structure of temporality cannot co-exist with contemporary capitalism, which cannot have a portion of the population living according to the rhythm of the land, in charge of itself. Clock time must be imposed, presupposed, assumed, everywhere asserted. Without clock time and its associated serial temporal logic, according to the dominant order there is only chaos. Time must be structured so production and leisure/ consumption are rigorously separated. So they can be measured. And production can be increased. And increased. And increased.

Inninew/Inninewak (Cree) and Anishinabwe peoples have a concept, variously spelled as, for example, pimatisiwin. Pimatisiwin means, roughly, "the good life." Here the ethical good life is conflated with the happy life (rather than the injunction to be good as self-sacrificing). The concept of pimatisiwin comes from and expresses a world of generalized wealth: the wealth of bush peoples, a wealth casually ignored in the endless rush to "develop" the North. At the Ryoanji Temple in Kyoto, Japan, an ancient stone wash basin, perhaps from the seventeenth century, is inscribed with the words "I learn only to be contented," a Zen concept implying "the one who does not learn to be contented is spiritually poor even if he is materially wealthy." Something of this is also conveyed in the concept of pimatisiwin.

\section{Inequality in Indigenous Northern Canada}

This rather abstract argument has too many "real world" implications. But at a minimum, it means that when inequality is discussed in relationship to the North, the core of the conversation should not be about wage disparities between the owners of businesses and the workers. This is indeed an issue, but only, or largely, for the growing non-Aboriginal population of the provincial and Far North of Canada. For Indigenous people, inequality is not about disparities of capital or income. Rather, the issue is about how a way of life not adequately captured by any statistical model is under attack from all sides: from the business interests that lust for untrammelled control of the land, to state interests that want to produce 
a population of docile bodies that behave like all the other docile bodies, to popular culture that demands its products be desired, to the systems of temporality and spatiality within which all the institutions-even those that desire healing or education or the administration of justice-operate.

Inequality in the North, in this sense, is really about unequal access to decision-making power. The conference rooms in which land allotments are parcelled out to industry, the board rooms in which decisions are made about which of those allotments will be probed and prodded to determine whether or what resources they may hide, the legislative systems and actors who decide how and when and by whom these rooms will be occupied-these are the rulers of a colonial inequality that reproduces itself every day in contemporary Canada.

A policy framework concerned with inequality in the conventional sense will therefore remain profoundly misguided in its application to the North and will, in fact, sit comfortably on the colonial side of the social divide. It is not that inequality is not an urgent problem globally. It is. And it must be urgently addressed. But in the North, a struggle against inequality can become another excuse to destroy the forms of wealth that do exist and that continue to be underestimated.

It is worth remembering here that the infamous White Paper (or Statement of the Government of Canada on Indian Policy, 1969) by Trudeau the First was, in fact, a policy aimed at reducing inequality. It was a policy in part inspired by the United States civil rights movement of the early 1960s. It was a social justice initiative. And it was soundly and convincingly rejected by a generation of Aboriginal leaders, who viewed prior occupancy and the fact that Canada was their cultural homeland as a basis for positive difference, first characterized as the concept of "citizens plus" and then understood as Aboriginal and treaty rights. Indigenous people in Canada, including and perhaps especially in the North, have not been first and foremost concerned with equality rights, but rather with cultural difference reflected in the doctrine of Aboriginal rights.

Yes, there is real poverty in Indigenous communities. There is appalling and overcrowded housing, poor infrastructure, food insecurity, joblessness, social dysfunction, poverty, and misery. Destroying the strengths that do exist-the hunting families, the Elders, the land base, the community as a community, the way of life-will not alleviate the problems. These strengths of northern life are what separate Indigenous communities from being entirely impoverished. They continue to be misunderstood and underappreciated. Any social program that does not start from this understanding will likely end up attacking and destroying 
the strengths that exist on the ground, the bush wealth of Indigenous hunting peoples, and will thereby contribute to a colonial divide that immiserates. The challenge is to find a way to strengthen the bush economy, to give the hunting peoples at least an equal place in decision making, to recognize the forms of wealth that do exist and strengthen the access to them. Such a challenge means confronting the logic of the racial reconfiguration and redistribution of wealth, a logic that Canada is founded upon and in every fibre of its being continues to perpetuate.

\section{Author}

Peter Kulchyski is professor and graduate program director of the Department of Native Studies at the University of Manitoba.

\section{Sources}

Coulthard, Glen. 2014. Red Skin, White Masks: Rejecting the Colonial Politics of Recognition, Minneapolis: University of Minnesota Press.

Fanon, Franz. 1996. The Wretched of the Earth. Translated by Constance Farrington. New York: Grove Press.

Harvey, David. 2003. The New Imperialism. New York: Oxford University Press.

Kulchyski, Peter. 1992. "Primitive Subversions: Totalization and Resistance in Native Canadian Politics." Cultural Critique 21 (1992): 181-182.

Kulchyski, Peter. 2005. Like the Sound of a Drum: Aboriginal Cultural Politics in Denendeh and Nunavut. Winnipeg: University of Manitoba Press.

Marx, Karl. 1977. Capital. Volume 1. Translated by Ben Fowkes. New York: Vintage Books.

Picketty, Thomas. 2014. Capital in the Twenty-First Century. Translated by Arthur Goldhammer. Cambridge: Harvard University Press.

Sahlins, Marshall. 1972. Stone Age Economics. Chicago: Aldine-Atherton.

Thompson, E. P. 1993. Customs in Common. New York: The New Press. 